\title{
ALTERNATÍV ANYAGOK ÉS TERVEZÉSI METODIKÁK HASZNÁLATA A KORTÁRS DESIGNBAN
}

\section{ALTERNATIVE MATERIALS AND METHODOLOGY IN CONTEMPORARY DESIGN}

\author{
Darabos Anita, ${ }^{1}$ Szalai Judit ${ }^{2}$ \\ Budapesti Müszaki és Gazdaságtudományi Egyetem, Budapest, Magyarország \\ 1 darabos.anita@gt3.bme-hu \\ 2 szalaijudit2018@gmail.com
}

\begin{abstract}
Nowadays, the increasing and destructive impact of mankind on the environment and related concerns have influenced and changed the paradigms of product development so far and have led to the appearance of an environmental dimension in the creation and design of new products. Numerous industrial sectors have changed their production processes to meet the ecological requirements that are included in product development. Issues such as the scarcity of natural resources, increasing consumption and increasing environmental pollution also present a number of problems. It is primarily used for the use of rare natural materials and resources that are extracted and processed.
\end{abstract}

Keywords: alternative materials, design methodology, contemporary design, eco-design, sustainable development.

\section{Összefoglalás}

Napjainkban az emberiség növekvő hatásának és a környezetre gyakorolt romboló hatásának aggályai befolyásolták és megváltoztatták a termékfejlesztés paradigmáit, ami a környezetvédelmi szempontok megjelenését eredményezte az új termékek létrehozásában és tervezésében. Az olyan problémák, mint a természeti erőforrások szűkössége, a növekvő fogyasztás és a növekvő környezetszennyezés is számos problémát jelentenek. Számos ipari ágazat megváltoztatta termékfejlesztési és termelési folyamatait, hogy megfeleljenek az ökológiai követelményeknek. A cikk bemutatja a kidolgozott új alternatívák specifikus döntéstámogató módszertannal való összehasonlításának folyamatát.

Kulcsszavak: alternatív anyagok, tervezési metodikák, kortárs design, ökodesign, fenntartható-fejlődés.

\section{1. Új tervezési metodikák a kortárs designban}

A fenntartható tervezés prioritásai mind az emberek, mind a környezet igényeit ki kell, hogy elégítsék, arra törekedve, hogy kihasználják a vízés energiafogyasztást csökkentő technológiákat, anyagokat és tervezési metódusokat.

A szakirodalom különböző feltételeket határoz meg, amelyeknek a megújuló energiaforrások területén alkalmazott, több szempontú döntési eljárásoknak meg kell felelniük. Napjainkban inten- zív kutatási területté vált a termékfejlesztésben a többszempontos döntési módszerek (Multi-Criteria Decision Making, MCDM) anyagválasztási folyamatokban való felhasználása. A tanulmány egy olyan fejlesztési igényekre kialakított többszempontos döntési módszer alkalmazását mutat be, amely támogatja a zajvédő falak tervezési és anyagválasztási feladatainak kidolgozásában résztvevő designer munkáját.

Elsőként Opricovic [1] vizsgálta az 1998-ban publikált VIKOR (Vise Kriterijumska Optimizacija I Kompromisno Resenje), módszert, amely az 
alternatívák rangsorolásra és azok kompromiszszumos kiválasztásra összpontosít, nehezen öszszeegyeztethető kritériumok esetén.

A VIKOR módszer döntéstámogatási alkalmazásának előnyeit és korlátait tervezéselméleti esettanulmány felhasználásával mutatjuk be. Az eredmények bemutatása után, következtetéseket vonunk le és javaslatokat vetünk fel a módszertan további alkalmazási lehetőségeire.

\subsection{Zajvédő falak tervezése}

A civilizált társadalmak felgyorsult technikai fejlődése együtt jár a lakott környeztük jelentősen növekedő zajtermelésével. A forgalom és a menetsebesség ugrásszerű megemelkedése, az ipari technikák profitorientáltsága miatt. A fokozott környezetszennyezés ezen belül a zaj elleni védekezés új kihívásokat jelentenek. Olyan új anyagok, konstrukciók alkalmazására van szükség, amelyek az akusztikai követelmények teljesítésén túl az építés, a használat során is gazdaságosnak és jól illeszthetők a telepítési környezetbe.

Közlekedési zajnak tekintjük a közúton, valamint az egyéb közlekedési területeken lévő járművek által a burkolatokon keltett és a működtetésükből származó zajokat. Zajszennyezésnek tekintjük a zajforrások által a környezetbe jutó káros, általában határérték feletti zajterhelést.

Zajárnyékoló (vagy zajvédő) létesítménynek tekintjük azokat a természetes, vagy épített aka-

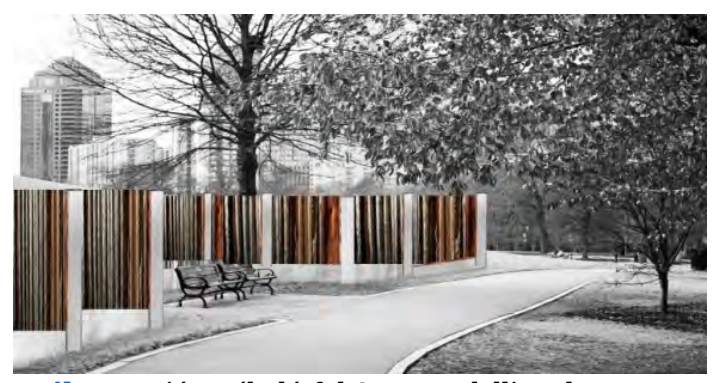

1. ábra. Zajárnyékoló fal 3D-s modellje: alapanyaga: fa, porcelán, kerámia, üveg [2]

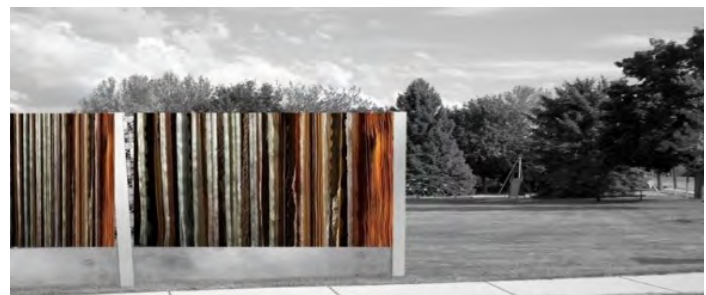

2. ábra. Zajárnyékoló fal 3D-s modellje: alapanyaga: fa, porcelán, kerámia, üveg [2] dályokat, amelyeket a zajforrás és a zaj ellen védendő terület, illetve épület közé helyezve a közlekedésből eredő zajt árnyékolják, csökkentik. A zajárnyékoló létesítmény zajcsökkentő hatása a zajárnyékolási jelenségen alapul. A megfelelően méretezett zajárnyékoló fal esetén a védendő létesítmény a fal akusztikai árnyékában van, azaz csak hullámelhajlás útján, a fal éleit, széleit megkerülve jut el a védendő létesítményhez a zaj. A zajárnyékoló létesítménnyel elérhető zajcsökkentés nagysága [2] 6-13 dB. (1-2. ábra).A zajvédő fal újrahasznosított anyagokból van, beton alsó lábazattal, szabványos oldalt rögzítő oszlopokkal. A fal alsó-felső tengelyes rögzítő elemmel van ellátva.

Az anyagvizsgálati eredmények prototípus modellek, illetve szimulációs vizsgálatok alapján jöttek létre. A vizsgálatok során az alábbi anyag összeállításokat és kialakításokat vizsgáltuk:

I. 2 m-es magasságú zajárnyékoló falak: -A1: egyenes zajárnyékoló fal (3. ábra.) -A2: hullám formájú zajárnyékoló fal (4. ábra.)

\subsubsection{Zajvédő falak tervezésének alapkritéri- umainak meghatározása}

A zajárnyékoló fallal elérhető zajcsökkentés, azaz a beiktatási veszteség frekvenciafüggő menynyiség, és függ a zajforrás típusától (pontforrás, vonalforrás) frekvencia színképétől is. Ezeken túlmenően befolyásolják:

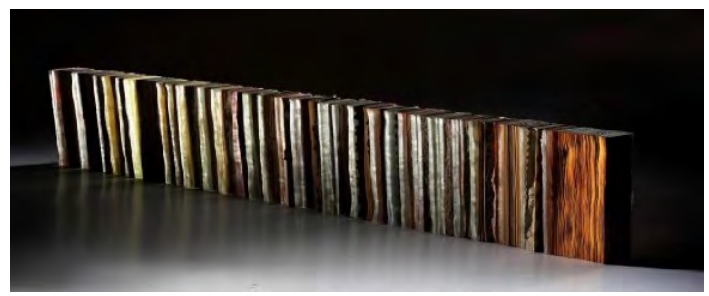

3. ábra. Egyenes zajárnyékoló fal kompozit prototípusa: alapanyaga: fa, porcelán, kerámia, üveg [2]

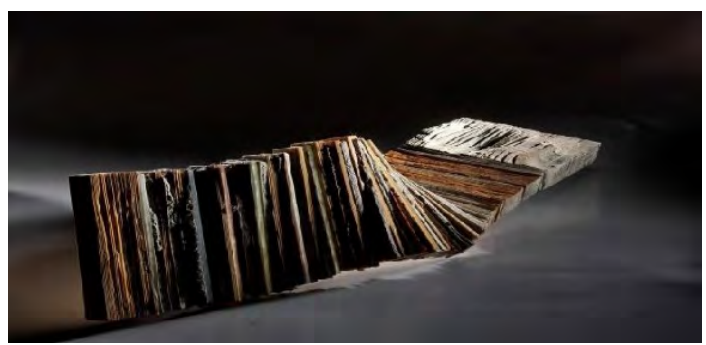

4. ábra. Hullám formájú zajárnyékoló fal kompozit prototípusa: alapanyaga: fa, porcelán, kerámia, üveg [2] 
- a fal geometriai méretei (magasság, hosszúság);

- a fal szerkezete, formai kialakítása, - akusztikai tulajdonságai (hangelnyelés, hanggátlás);

- a fal vastagsága;

- a telepítés geometriai adatai, a zajforrás, védendő létesítmény magassága, helyzete, a fal;

- a zajforrás és a védendő létesítmény egymáshoz viszonyított elhelyezkedése;

- földhatás miatt fellépő reflexió;

- a telepítési viszonyok (környező földfelület, növényzet, épületek stb.);

-meteorológiai viszonyok. [3]

\subsubsection{A rendelkezésre álló anyagválasztási alternatívák értékelése}

A különböző alternatívál közötti döntési feladatokra jellemző, hogy mindegyik alternatívának lehet előnyös és hátrányos oldala, melyet optimá-

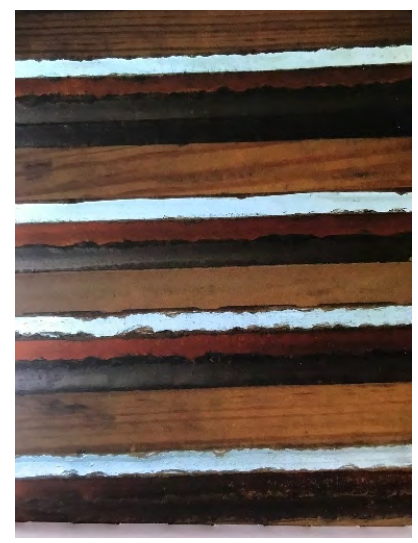

5. ábra. Zajárnyékoló fal felépitése: alapanyaga: fa, porcelán, kerámia, üveg [2] lisan döntéstámogató módszerrel oldhatunk meg. 7. ábra.

Az alternatívákat összehasonlító eljárás során figyelembe vett szempontok és azok fontossági értékeit mutatja be az 1. táblázat.

A megtervezett alternatívák modelljeinek és az azokon elvégzett értékelési szempontok eredményeinek feldolgozásával, az alternatívákat Excel programban rangsoroltuk a VIKOR módszer matematikai modelljét felhasználva. [1]

$\mathrm{Az}$ értékelési folyamat eredményeit (rangsor: A1>A2) mutatja be az 2. táblázat.

A VIKOR módszer rangsor meghatározásának eredményeként, az alternatívák közül az első alternatíva (A1) lett a jobb a rangsorolásban, illetve a második alternatíva (A2) volt az, ami a rangsor végére került.

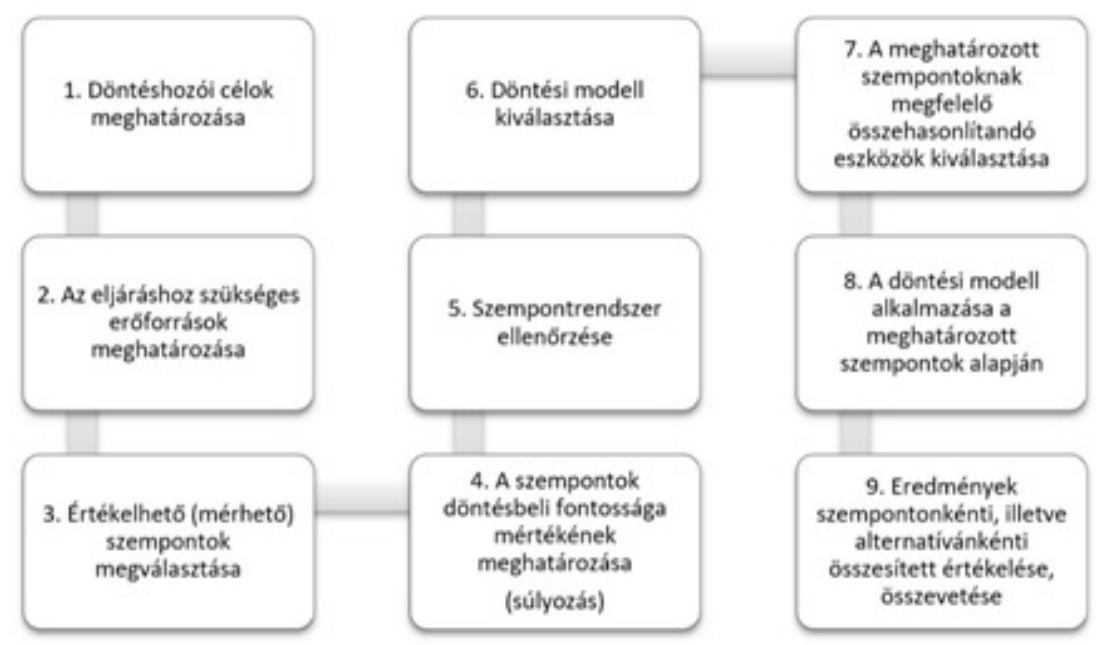

7. ábra. A prototípusok összehasonlítási folyamata döntéstámogató módszertannal [4] 
1. táblázat. Az összehasonlító eljárás során figyelembe vett szempontok és azok fontossági értékei

\begin{tabular}{|l|l|c|}
\hline & Értékelési szempontok & Fontosság \\
\hline C1 & Költségigény & 9 \\
\hline C2 & Időigény & 6 \\
\hline C3 & Megbízhatóság & 10 \\
\hline C4 & Technológia & 8 \\
\hline C5 & Anyaghasználat & 5 \\
\hline C6 & Konstrukciós kialakítás & 8 \\
\hline
\end{tabular}

2. táblázat. Az alternatívákat összehasonlító eljárás során figyelembe vett szempontok és azok fontossági értékei

\begin{tabular}{|l|l|l|l|l|l|l|}
\hline Alt. & \multicolumn{7}{|c|}{ Szempontok } \\
\hline & C1 & C2 & C3 & C4 & C5 & C6 \\
\hline A1 & 9 & 6 & 1 & 8 & 50000 & 8 \\
\hline A2 & 9 & 6 & 1 & 7 & 50000 & 8 \\
\hline Súly & 0,216 & 0,086 & 0,307 & 0,146 & 0,15 & 0,76 \\
\hline
\end{tabular}

\section{Következtetések}

A tanulmányban a többszempontú értékelési módszerek felhasználási területeinek vizsgálatára fektettünk hangsúlyt, kiemelten a VIKOR módszerre, amely ígéretes megoldást nyújt az alternatív anyagok megítélésében a tervezési folyamat során. Az itt bemutatott tervezési metodika felhasználása jelentős kutatási érdeklődést vetít előre az ökodesign területén.

\section{Köszönetnyílvánítás}

A tanulmány alapjául szolgáló kutatást az Emberei Erőforrások Minisztériuma által meghirdetett Felsőoktatási Intézményi Kiválósági Program támogatta, a Budapesti Műszaki és Gazdaságtudományi Egyetem Mesterséges intelligencia (BME FIKP-MI) tématerületi programja keretében.

\section{Szakirodalomi hivatkozások}

[1] Opricovic, S.: Multicriteria Optimization of Civil Engineering Systems. PhD Thesis, Faculty of Civil Engineering, Belgrade, (1998) 1-205.

[2] Polatidis H.: Selecting an appropriate multicriteria decision analysis technique for renewable energy planning. Energy Sources, (2006) 190. oldal

[3] Közlekedési szakcsoport, Pálffy M: A közlekedési zaj figyelembevételének szabályai. (letöltve: 2018.11.10.).

http://fmmk.hu/kozlekedes/wp-content/uploads/2016/08/A-K\%C3\%96ZLEKED\%C3\%89SI-ZAJ-FIGYELEMBEV\%C3\%89TELe.pdf

[4] Darabos Anita: Növényi épitészet, állati épitészet, természeti épitmények. PhD értekezés, Pollack Mihály Müszaki Kar, Pécs 2-17.

https://pea.lib.pte.hu/bitstream/handle/ pea/14442/darabos-anita-tezis-hun-2016.pdfn2016.pdf?sequence $=2$

[5] Ali J.: Multicriteria Decision Analysis for Supporting the Selection of Engineering Materials in Product Design. 2. kiadás. Butterworth-Heinemann, Oxford, 2013. 100-252. 